\title{
Endocrine and metabolic differences between Bos taurus and Bos indicus cows and implications for reproductive management
}

\author{
R. Sartori ${ }^{1,3}$, P.L.J. Monteiro Jr. ${ }^{1}$, M.C. Wiltbank ${ }^{2}$ \\ ${ }^{1}$ Department of Animal Science, ESALQ, University of São Paulo (USP), Piracicaba, SP, Brazil. \\ ${ }^{2}$ Dairy Science Department, University of Wisconsin, Madison, USA.
}

\begin{abstract}
clearance rates of steroid hormones in $B$. indicus than $B$. taurus, the dose of $2 \mathrm{mg}$ estradiol benzoate seems to be the most effective either for Nelore (B. indicus beef), Angus (B. taurus beef), or Holstein (B. taurus dairy) cows at the initiation of an E2/P4-based FTAI protocol to optimize synchronization and pregnancy per AI (P/AI). Several studies have shown that only one recommended dose of PGF2 $\alpha$ at a FTAI protocol may be insufficient for adequate luteolysis in $B$. indicus and $B$. taurus. When submitted to multiple ovulation and embryo transfer, $B$. indicus cows and heifers need less FSH than $B$. taurus to achieve superovulation. Moreover, IVP has been more successful in $B$. indicus than $B$. taurus due to greater antral follicle count and anti-mullerian hormone, and better oocyte quality.
\end{abstract}

Abstract function, as well as circulating hormones and metabolites between these two genetic groups.

Currently, researchers are using this acquired knowledge to optimize protocols for fixed-time artificial insemination (FTAI), and production of in vivo derived (IVD) embryos by multiple ovulation or by in vitro embryo production (IVP). Accordingly, this manuscript is divided into sections that describe: 1) Differences in reproductive physiology between $B$. indicus and $B$. taurus, 2) Practical implications of the physiological differences between B. indicus and B. taurus for FTAI protocols, and 3) Practical implications of the physiological differences between $B$. indicus and $B$. taurus for embryo production.

Because Nelore (B. indicus) and Holstein ( $B$. taurus) are among the principal beef and dairy cattle breeds used in Brazil, respectively, they are the most representative of the studies discussed in this article.

\section{Differences in reproductive physiology between $B$. indicus and B. taurus}

Keywords: artificial insemination, embryo transfer, Holstein, hormone, metabolism, Nelore.

\section{Introduction}

Recent studies have gathered a great deal of knowledge on the reproductive physiology of Bos indicus (B. indicus) heifers and cows, especially by performing direct comparisons with Bos taurus (B. taurus) under similar environmental, nutritional, and management conditions. Those studies have identified considerable differences in ovarian morphology and
During the last decade, there was a substantial increase in studies that compared reproductive physiology variables between $B$. indicus and $B$. taurus. Although below we present a summary of those results, and a compilation of data represented in Fig. 1 and Table 1, the aim of this manuscript is not to extensively describe those data. Therefore, for detailed information, we suggest that the reader consult the publications cited in this review article.

The average ovarian antral follicle count (AFC) in B. indicus is twice the number observed for B. taurus (Fig. 1; Table 1). For example, at wave emergence, the number of 2 to $5 \mathrm{~mm}$ follicles present in the ovaries was 42.7 (ranging from 25 to 100) in Nelore and 19.7 (ranging from 5 to 40) in Holstein cows (Bastos et al., 2010). Greater AFC has been associated with greater circulating anti-mullerian hormone (AMH) in $B$. indicus as compared to B. taurus (Baldrighi et al., 2014; Batista et al., 2014). Another observed difference between $B$. taurus and $B$. indius was the size of largest follicle at ovulatory follicle at the time of deviation was between 8.3 and $9.8 \mathrm{~mm}$ (Ginther et al., 1996; Sartori et al., 2004; Bastos et al., 2010). In Nelore heifers, deviation happened when the largest follicle reached 5.4 to $6.2 \mathrm{~mm}$ (Sartorelli et al., 2005; Gimenes et al., 2008), and in nonlactating Nelore cows between 7.0 and $7.4 \mathrm{~mm}$ of deviation. In Holstein cattle, the diameter of the future 
diameter (Bastos et al., 2010; Sartori et al., 2016). Nevertheless, the time after ovulation or after wave emergence for follicle deviation was similar between $B$. taurus and B. indicus (Sartori et al., 2010a, 2016; Fig. 1) due to a slower growth rate of the follicle in Nelore $(0.8$ to $1.2 \mathrm{~mm} / \mathrm{d}$; Gimenes et al., 2008; Sartori and Barros, 2011) than Holstein cattle (1.2 to $1.6 \mathrm{~mm} / \mathrm{d}$; Sartori et al., 2001).
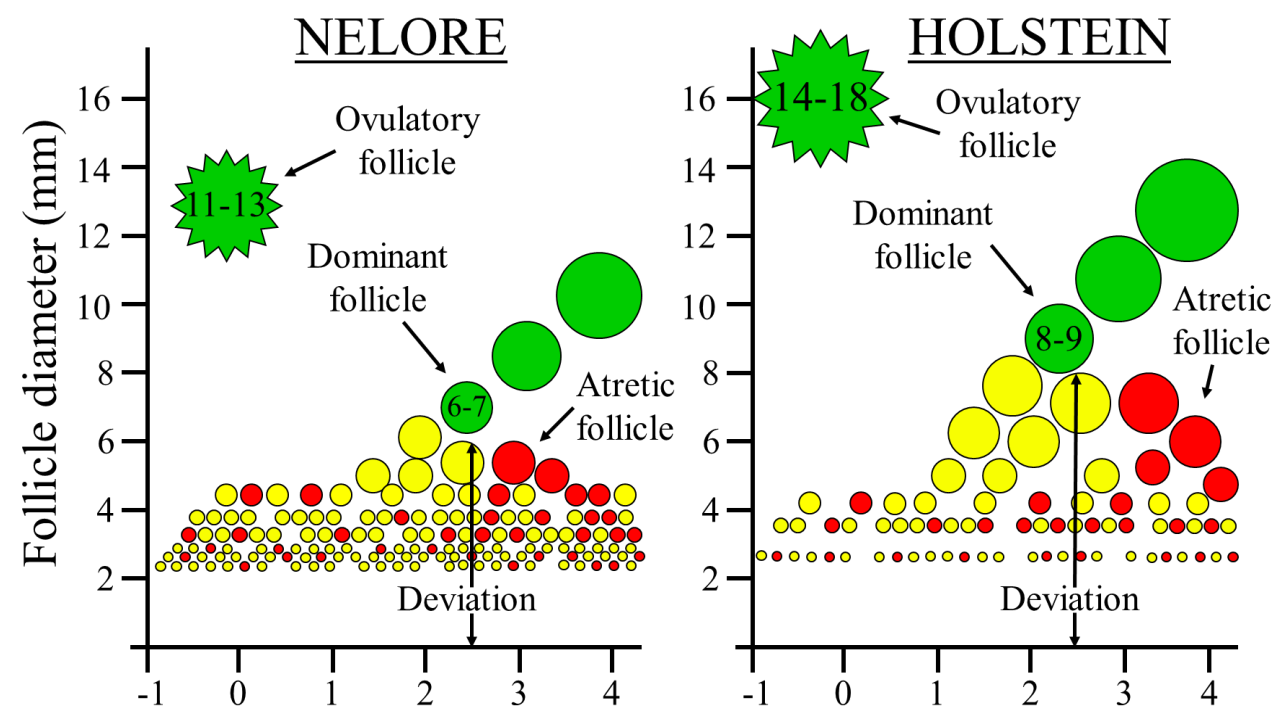

Days after ovulation

Figure 1. Schematic representation of follicle development in Nelore (B. indicus) and Holstein (B. taurus) cows based on data from the literature and personal data. Nelore have a greater population of small (2 to $5 \mathrm{~mm})$ follicles in the ovaries throughout the entire estrous cycle than Holstein cattle. Moreover, although both breeds have follicle deviation between day 2 and 3 after ovulation, the diameter of the future dominant follicle at deviation is greater in Holstein cattle. The diameter of the ovulatory follicle is also greater in Holstein than Nelore cows (From Sartori et al., 2010a).

Although follicle deviation occurs in $B$. indicus when the dominant follicle reaches 5 to $7.5 \mathrm{~mm}$ in diameter compared to 8 to $10 \mathrm{~mm}$ in B. taurus, it is possible that additional growth is necessary for the dominant follicle to acquire ovulatory capacity in both breeds. Sartori et al. (2001) observed that Holstein cows with follicles 7 or $8.5 \mathrm{~mm}$ in diameter did not ovulate, even after administration of high doses of pLH (40 mg). However, $80 \%$ of the cows with follicles $\geq 10 \mathrm{~mm}$ ovulated after pLH administration. Conversely, Gimenes et al. (2008) reported that administration of 25 $\mathrm{mg} \mathrm{pLH}$ in $B$. indicus heifers induced ovulation in 33.3 , 80.0 and $90.0 \%$ of animals with follicles that were 7.0 to $8.4,8.5$ to 10 and $>10 \mathrm{~mm}$ in diameter, respectively.

Diameter of the largest ovulatory follicle and of the corpus luteum (CL) also differs between $B$. taurus and $B$. indicus. B. taurus have larger diameter of ovulatory follicle (Fig. 1) and greater CL volume than $B$. indicus. However, circulating concentration of steroid hormones in B. taurus are lower than in $B$. indicus (Sartori and Barros, 2011; Sartori et al., 2016). In studies with Nelore cattle, the diameter of ovulatory follicle was between 11 and $14 \mathrm{~mm}$ (Figueiredo et al., 1997; Sartorelli et al., 2005; Sartori et al., 2016), and the maximum diameter of the ovulatory follicle in Holstein cattle was between 13 and $19 \mathrm{~mm}$ (Ginther et al., 1989; Sartori et al., 2002a, 2004). Similarly, the CL diameter of $B$. indicus ranged from 17 to $21 \mathrm{~mm}$ or $\sim 2.5$ to $5.0 \mathrm{~cm}^{3}$ (Segerson et al., 1984; Rhodes et al., 1995; Figueiredo et al., 1997; Bó et al., 2003; Sartori et al.,
2016), whereas the CL diameter of B. taurus ranged from 20 and $30 \mathrm{~mm}$ or $\sim 4.0$ to $14.0 \mathrm{~cm}^{3}$ (Ginther et al., 1989; Bó et al., 2003; Sartori et al., 2004, 2016).

Despite having larger follicles and CL, B. taurus have lower circulating steroid hormone concentrations. For example, we have shown that non-lactating Holstein cows had larger ovulatory follicle diameter (14.2 vs. $12.9 \mathrm{~mm})$ and CL volume $\left(5.2\right.$ vs. $\left.3.9 \mathrm{~cm}^{3}\right)$ than nonlactating Nelore cows (Sartori et al., 2016); however, Holstein cows had a lower preovulatory peak of circulating estradiol (E2; 12.5 vs. $16.2 \mathrm{pg} / \mathrm{ml})$ and circulating progesterone $(\mathrm{P} 4)$ concentrations (1.9 vs. $2.7 \mathrm{ng} / \mathrm{ml}$ ) on day 7 of the estrous cycle compared with Nelore cows.

This inverse relationship between size of ovarian structures and circulating hormone steroids may be related to the reported differences in circulating insulin, IGF1, and cholesterol between breeds. Most of the studies have described greater circulating insulin and IGF1 in B. indicus than in B. taurus (Alvarez et al., 2000; Sartori et al., 2010b, 2013). Moreover, it has also been reported that, under similar nutrition management conditions, Nelore heifers have $\sim 60 \%$ greater circulating cholesterol (precursor for the biosynthesis of steroid hormones) than Holstein heifers (196.8 vs. $123.5 \mathrm{mg} / \mathrm{dl}$; Gandra et al., 2011). The potential effects of metabolic hormones or other substances on either different clearance rates of steroid hormones or E2 and P4 production by ovarian structures are discussed by Sartori et al. (2016). 
Table 1. Comparison of reproductive variables between B. indicus and B. taurus.

\begin{tabular}{|c|c|}
\hline & B. indicus vs. B. taurus \\
\hline Estrous cycle length & $=$ \\
\hline Day of luteolysis & $\leq$ \\
\hline Number of waves per cycle & $>$ \\
\hline Ovarian antral follicle count & $>$ \\
\hline Circulating AMH & $>$ \\
\hline Size of dominant follicle at deviation & $<$ \\
\hline Day of deviation after ovulation & $=$ \\
\hline Growth rate of dominant/ovulatory follicle & $<$ \\
\hline Maximum size of dominant/ovulatory follicle & $<$ \\
\hline Estradiol peak preceding ovulation & $>$ \\
\hline Duration of estrus & $\leq$ \\
\hline Luteal tissue volume & $<$ \\
\hline Circulating progesterone & $>$ \\
\hline Steroid hormones clearance rate & $<$ \\
\hline Circulating insulin & $>$ \\
\hline Circulating IGF1 & $>$ \\
\hline Circulating FSH & $\leq$ \\
\hline Circulating cholesterol & $>$ \\
\hline
\end{tabular}

\section{Practical implications of the physiological differences between Bos indicus and Bos taurus for FTAI protocols}

Artificial insemination is an important tool for genetic improvement. However, suboptimal estrus detection rates in cycling cows (Pinheiro et al., 1998; Lopez et al., 2004; Sartori and Barros, 2011; Fricke et al., 2014) and a substantial percentage of postpartum cows that are not cycling (Wiltbank et al., 2002; Meneghetti et al., 2009; Santos et al., 2009), produce the problem of low service rates (SR) in $B$. indicus and $B$. taurus. Thus, AI programs based on estrus detection may have lower reproductive efficiency and less costbenefit than FTAI programs (Ribeiro et al., 2012).

The FTAI program allows for a large number of cows to be inseminated on the same day, with high reproductive efficiency and relatively low cost. Nevertheless, the success of the FTAI program depends on several factors, such as synchronization of follicular waves to optimize the period of follicular dominance in order to not ovulate too old (Cerri et al., 2009) or too young (Vasconcelos et al., 2001) of a follicle; synchronization of corpus luteum (CL) function and circulating P4; complete luteolysis at the end of the protocol; and synchronization of final ovulation with optimally scheduled FTAI.

\section{Synchronization of emergence of follicle wave}

There are two main methods for follicle wave emergence synchronization used in dairy and beef cattle: GnRH-based protocols, in which in the presence of a dominant follicle, GnRH induces ovulation and a new follicle wave starts (Pursley et al., 1995), or E2/P4based protocols, that induces regression of all follicles present in the ovaries and a new wave starts within the following days, depending on the E2 ester used (Bó et al., 2003). In GnRH-based programs in dairy cattle, about 50 and $70 \%$ of the cows have a new wave properly synchronized by the Ovsynch and DoubleOvsynch programs, respectively (Giordano et al., 2012a). In E2/P4-based program in dairy cows about $70 \%$ of the cows have a new wave properly synchronized (Monteiro Jr et al., 2015a).

Effectiveness of GnRH-based protocols for follicle wave emergence in $\mathrm{B}$. taurus and $\mathrm{B}$. indicus

There are several factors that influence the proportion of cows ovulating to a GnRH/LH surge at the initiation of a FTAI protocol, such as day of the estrous cycle (Vasconcelos et al., 1999) or follicle diameter (Sartori et al., 2001; Gimenes et al., 2008). Although GnRH-based protocols have been successfully used in B. taurus cows (Pursley et al., 1995, 1997; Bridges et al., 2008), but not necessarily in B. taurus heifers (Pursley et al., 1995, 1997), there are conflicting data regarding their effectiveness in $B$. indicus cows (Fernandes et al., 2001; Bó et al., 2003; Baruselli et al., 2004; Ferraz Jr et al., 2016). Below, we describe results of experiments that may explain why GnRH-based protocols may have had suboptimal outcomes in the studies cited above.

Because it has been shown that B. taurus did not have consistent ovulation to a GnRH treatment even in the presence of a dominant follicle $>10 \mathrm{~mm}$ in diameter (Martinez et al., 1999; Perry and Perry, 2009), factors other than follicle size, such as circulating concentration of P4, may affect ovulation to GnRH. For example, a study (Biehl et al., 2013) compared ovulatory response to the first $\mathrm{GnRH} \quad(100 \mu \mathrm{g}$ gonadorelin) treatment of the 5 days CO-Synch+CIDR program in Nelore heifers. The treatments were: HiP4 $(\mathrm{n}=62 ; \mathrm{GnRH}$ in heifers with a CL present at P4 device insertion); LoP4 $(\mathrm{n}=35$; GnRH in heifers with no $\mathrm{CL}$ present at P4 device insertion); and PGF-LoP4 ( $\mathrm{n}=65$; GnRH in heifers that had a CL but were treated with 25 $\mathrm{mg}$ of dinoprost [PGF] 2 days before GnRH treatment and $\mathrm{P} 4$ device insertion). Ovulation to $\mathrm{GnRH}$ was 
greater for LoP4 (85.7\%) and PGF-LoP4 (95.4\%) compared with the HiP4 (25.8\%). Melo et al. (2016) have also shown a negative correlation between circulating P4 and ovulatory response to GnRH. Lack of ovulation to $\mathrm{GnRH}$ is likely related to the negative relationship between circulating concentration of $\mathrm{P} 4$ and magnitude of the GnRH-induced LH surge, which has been demonstrated in B. taurus heifers or cows (Colazo et al., 2008; Perry and Perry, 2009; Giordano et al., 2012a). For example, treatment with $100 \mu \mathrm{g}$ of GnRH in the presence of high $v s$. low $\mathrm{P} 4$ resulted in a much lower peak of the LH surge $(3.3 v s .15 .7 \mathrm{ng} / \mathrm{ml})$. Nevertheless, greater doses of $\mathrm{GnRH}$, even in the presence of elevated $\mathrm{P} 4$, can result in a greater magnitude of the LH surge and greater ovulation (Giordano et al., 2013). Moreover, it is possible that different analogs of GnRH may produce different outcomes, because it has been reported, for example, that gonadorelin induced a lower LH surge compared with other analogs of $\mathrm{GnRH}$, such as lecirelin, fertirelin, or buserelin (Chenault et al., 1990; PicardHagen et al., 2015). Although the magnitude of a GnRHinduced LH surge in the presence of low $v s$. high $\mathrm{P} 4$ has not yet been tested in $B$. indicus, it seems likely that this problem may underlie some of the observed lack of ovulation to $\mathrm{GnRH}$ treatment in these cattle.

Thus, GnRH-based protocols are likely to have lower synchronization of the first follicular wave when they are initiated in the presence of a CL, primarily due to lack of ovulation of a dominant follicle at the initiation of the protocol. This is clearly related to the greatly reduced magnitude of the $\mathrm{LH}$ surge induced by $\mathrm{GnRH}$ in the presence of elevated P4. In addition, due to natural growth and regression of follicular waves during the luteal phase there are many times when an LHresponsive dominant follicle is not present, and therefore ovulation would not occur even with an optimized LH surge. Further, the presence of elevated P4 may reduce LH receptor expression in the dominant follicle and this could reduce responsiveness to an $\mathrm{LH}$ surge in dominant follicles (Dias et al., 2014). In spite of reduced ovulation to GnRH in the presence of elevated P4, and therefore reduced follicular wave synchronization, fertility is generally relatively high in cows that are given the first GnRH of an Ovsynch protocol in the presence of elevated $\mathrm{P} 4$.

In contrast, in a low $\mathrm{P} 4$ environment, GnRH induces ovulation in a high proportion of lactating dairy cows (Gumen et al., 2003). A low P4 environment would be expected in anovular cows or cows in the proestrous phase of the estrous cycle. In these cows, ovulation to the GnRH treatment is essential for optimal fertility, as cows with low P4 at the initiation of the protocol that did not have ovulation to GnRH had greatly reduced fertility (Giordano et al., 2012b). Comparisons of the use of EB (2 mg) vs. GnRH at the beginning of a FTAI program have reported variable results. For example, Pereira et al. (2013a) compared the 5-days Cosynch protocol, a GnRH-based protocol, to an E2/P4 protocol in Holstein cattle $(\mathrm{n}=1,190)$ during the summer. They reported better synchronization rate for the GnRH compared to the E2 protocol (78.2 vs. 70.7\%; $\mathrm{P}=0.02)$. However, using only synchronized cows, percentage pregnant/AI (P/AI) was not different at the 32 days pregnancy diagnosis but was lower for GnRH than E2 at the 60 days pregnancy diagnosis $(17.7$ vs. $25.6 \% ; \mathrm{P}=0.03)$ due to greater pregnancy loss for $\mathrm{GnRH}$ than E2-treated cows $(21.7 \mathrm{vs}$. $6.7 \% ; \mathrm{P}=0.01)$. In contrast, in high-producing dairy cows $(\mathrm{n}=1,035)$, Melo et al. $(2016)$ reported that, even with a low ovulation rate to GnRH (gonadorelin; 35\%) at the beginning of the protocol, cows that received GnRH tended to have greater P/AI that those receiving $\mathrm{EB}$ at the start of the protocol (38.2 vs. 33.7; $\mathrm{P}=0.07)$.

Many GnRH-based protocols in B. taurus now use presynchronization strategies to assure that cows are at a stage of the estrous cycle that optimizes ovulation to GnRH. For example, Double Ovsynch uses an Ovsynch protocol to presynchronize the cows so that almost all cows ( 94\%; Herlihy et al., 2012) are cycling and at day 6 or 7 of the estrous cycle at the start of the breeding Ovsynch protocol. This produces a high ovulation rate to GnRH and high fertility during the protocol. These presynchronization strategies have not been adequately tested in $B$. indicus but are likely to be too complicated for most $B$. indicus management systems. Unfortunately, studies have not yet been performed that directly tested the ovarian responses and fertility of B. taurus vs. B. indicus in response to the same GnRH-based protocols.

Effectiveness of E2/P4-based protocols for follicle wave emergence in $\mathrm{B}$. taurus and $\mathrm{B}$. indicus

Early studies that established the physiological basis for these protocols utilized beef heifers and found that treatment with different esters of E2 simultaneously with P4 treatment led to suppression of the gonadotropins, regression of growing follicles, and emergence a new follicular wave about 4 days after E2 treatment (Bo et al., 1993, 1994, 1995). Although E2/P4-based FTAI protocols are widely used in $B$. taurus and B. indicus (Martinez et al., 2000; Ayres et al., 2008; Meneghetti et al., 2009; Souza et al., 2009; Sá Filho et al., 2011; Pereira et al., 2013b; Monteiro Jr et al., 2015b), the metabolism of E2 is different between B. taurus and B. indicus (Sartori et al., 2016). For example, in a $3 \times 2$ Latin Square design study (Bastos et al., 2011), the effect of dose of estradiol benzoate (EB; 1,2 or $4 \mathrm{mg}$ ), given at the same time as a P4 intravaginal insert, on the synchronization of follicular wave emergence was evaluated in non-lactating Nelore $(\mathrm{n}=13)$ and Holstein $(\mathrm{n}=11)$ cows receiving a maintenance diet. The BCS and body weight were kept at $3.5 \pm 0.1$ and $3.0 \pm 0.2$ (scale of 1 to 5 ) and $535 \pm 14$ and $600 \pm 23 \mathrm{~kg}$ for Nelore and Holstein cows, respectively. Two doses of prostaglandin F2 $\alpha$ (PGF2 $\alpha$ ) were given 11 days apart, and simultaneously with the second PGF $2 \alpha$, cows were treated with EB and with an intravaginal P4 insert, which remained for 10 days. Ovarian dynamics were monitored daily by means of ultrasonography for 10 days after EB treatment. Only cows with follicular wave emergence synchronized by the protocol were included, i.e., when the emergence occurred between 1 and 6 days after treatment with EB + P4. In response to the treatments, $2.5 \%$ (1/39) of Nelore cows did not have a synchronized follicular wave emergence, with the only non-synchronized cow 
being treated with $1 \mathrm{mg}$ EB. As for Holstein cows, $15.1 \%(5 / 33)$ did not have a synchronized follicular wave emergence (three cows had received $1 \mathrm{mg}$ and the other two cows, 2 or $4 \mathrm{mg}$ EB). Regardless of breed, there was a dose-dependent effect of treatment with EB on the following variables: day of the follicular wave emergence, diameter of the dominant follicle 9 days after treatment with $\mathrm{EB}$, circulating concentration of E2 $24 \mathrm{~h}$ after treatment with EB, time that circulating FSH began to rise (beginning of FSH peak) after EB, and time of occurrence of the peak of circulating $\mathrm{FSH}$ (Table 2). The follicular wave emergence occurred $3.1 \pm$ $0.3^{\mathrm{a}}, 3.3 \pm 0.1^{\mathrm{ab}}$ and $3.9 \pm 0.2^{\mathrm{b}}$ days after treatment with 1 , 2, or $4 \mathrm{mg}$ of $\mathrm{EB}$, respectively $\left({ }^{\mathrm{a}, \mathrm{b}} \mathrm{P} \leq 0.05\right)$, independent of breed, although circulating concentrations of E2 $24 \mathrm{~h}$ after treatment with EB was much greater in Nelore than Holstein cows (Table 2). The diameter of the largest follicle 9 days after treatment was $12.2 \pm 0.5^{\mathrm{a}}$ $11.5 \pm 0.8^{\mathrm{ab}}$ and $9.9 \pm 0.7^{\mathrm{b}} \mathrm{mm}$ in cows that received 1,2 or $4 \mathrm{mg}$ of EB, respectively $\left({ }^{\mathrm{a}, \mathrm{b}} \mathrm{P} \leq 0.05\right)$, but there was no breed effect (Table 2). At follicle wave emergence, the number of 2 to $5 \mathrm{~mm}$ follicles present in the ovaries was greater in Nelore than in Holstein cows $(30.8 \pm 4.5$ vs. $13.6 \pm 1.1$ AFC; Table 2). Furthermore, follicle deviation occurred, on average, $3.0 \pm 0.2$ days after wave emergence, independent of breed, when the diameter of the largest follicle reached $7.3 \pm 0.4$ and $9.0 \pm 0.5 \mathrm{~mm}$ in Nelore and Holstein cows, respectively $(\mathrm{P}<0.05)$. It was concluded that the timing of follicle wave emergence after treatment with $\mathrm{EB}+\mathrm{P} 4$ was EB dosedependent for both breeds.

The results presented above are, somewhat, contradictory, because despite a very different clearance rate of E2 (same doses, but very distinct concentrations of circulating E2 after EB treatment [ $>2$-fold difference] in cows with little difference in body weight - Holsteins were only $12 \%$ heavier than Nelore cows), the behavior of wave emergence after EB + P4 treatment was not different between breeds (Table 2). Therefore, based on differences in circulating E2 after EB treatment between breeds, one might expect that lower EB doses should be used for Nelore and higher EB doses should be used for Holstein cattle at the initiation of an E2/P4-based FTAI protocol in order to optimize synchronization of follicle wave emergence. In contrast, based on the similar responses of both breeds to $\mathrm{EB}$ treatments in terms of follicle wave emergence, a similar E2 dose might be optimal for Nelore and Holstein cows.

Currently, both in B. indicus and B. taurus, the dose of EB recommended for initiation of a FTAI protocol is $2.0 \mathrm{mg}$ given at the same time as treatment with $\mathrm{P} 4 /$ progestin. However, hypothesizing that the dose of $2.0 \mathrm{mg}$ EB would be insufficient to effectively synchronize follicular wave emergence in lactating dairy cows, Monteiro Jr et al. (2015a) compared $2.0 \mathrm{vs.}$ $3.0 \mathrm{mg} \mathrm{EB}$ at the beginning of a FTAI protocol. All cows were treated with EB ( 2.0 or $3.0 \mathrm{mg}$ ) at the time of introduction of a P4 insert (day 0). On day 7, cows were given $25 \mathrm{mg}$ of PGF $2 \alpha$; on day 8 , the insert was removed and cows were given $1 \mathrm{mg}$ of estradiol cypionate (ECP). All cows received FTAI on day 10. Daily transrectal ultrasound evaluations of the ovaries were performed. There was no difference $(\mathrm{P}>0.10)$ between treatments with $3.0 v s .2 .0 \mathrm{mg}$ EB for proportion of cows with synchronized follicular wave emergence (71.4\% [15/21] vs. 82.6\% [19/23]), and time to wave emergence $(3.6 \pm 0.19$ vs. $3.4 \pm 0.17 \mathrm{~d})$. However, treatment with $3.0 \mathrm{mg}$ EB decreased the percentage of cows with a CL on day 7 of the FTAI protocol (19.8\% [4/17] vs. 55.3\% [13/21]; $\mathrm{P}<0.05)$, indicating that the higher dose of EB caused increased CL regression during the protocol.

Using similar reasoning as in the study of Bastos et al. (2011), a study was done in B. taurus and $B$. indicus beef cattle comparing 1.0 vs. $2.0 \mathrm{mg} \mathrm{EB}+\mathrm{P} 4$ at the initiation of a FTAI protocol. Pessoa et al. (2015) compared the treatments above during a resynchronization protocol starting 22 day (day 22) after the first FTAI and evaluated P/AI, pregnancy loss and induction of new follicular wave emergence in suckled beef cows. Thus, on day 22 after first FTAI all cows received an intravaginal $\mathrm{P} 4$ insert and, regardless of pregnancy status, 1426 cows (768 B. taurus and $728 \mathrm{~B}$. indicus) were treated with either 1 or $2 \mathrm{mg}$ EB. After 8 days (day 30), the P4 insert was removed and pregnancy diagnosis was accomplished by ultrasound. Nonpregnant cows were then treated with cloprostenol. On the same day, $B$. taurus cows received $10 \mathrm{mg} \mathrm{FSH}$ and 1 mg EB, whereas $B$. indicus cows were treated with 300 IU eCG and $1 \mathrm{mg}$ ECP. The FTAI was performed 44 or $48 \mathrm{~h}$ after $\mathrm{P} 4$ removal on $B$. indicus and $B$. taurus cows, respectively. Pregnancy diagnosis was conducted again at 62 days after first FTAI. The P/AI after the first FTAI was similar $(\sim 44.0 \%$; $\mathrm{P}=0.85)$ between treatments regardless of breed. However, P/AI after resynchronization was lower $(\mathrm{P}=0.0001)$ in cows treated with 1 compared to $2 \mathrm{mg}$ EB (36.1 vs. 47.3\%). Pregnancy loss at first FTAI was similar $(\mathrm{P}=0.37)$ between treatments (3.8vs. 5.5\% for 1 and $2 \mathrm{mg} \mathrm{EB})$, but the cumulative pregnancy was greater $(\mathrm{P}=0.01)$ in cows treated with $2 \mathrm{mg}$ EB $(68.2 \%)$ than those treated with $1 \mathrm{mg}$ EB (62.8\%). Moreover, B. indicus cows had ovarian dynamics evaluated by ultrasound to assess induction of a new follicular wave emergence after treatment with $1 \mathrm{mg}(\mathrm{n}=12)$ vs. $2 \mathrm{mg}(\mathrm{n}=12) \mathrm{EB}$. Despite a similar interval from $\mathrm{EB}$ treatment to new follicular wave emergence ( $\mathrm{P}=0.13)$, the emergence of a new wave was more dispersed $(\mathrm{P}=0.03)$ in cows treated with $1 \mathrm{mg}$ EB $(1.8 \pm 1.3 \mathrm{~d})$ compared with cows treated with $2 \mathrm{mg}$ EB $(2.3 \pm 0.6 \mathrm{~d})$. Therefore, a dose of $2 \mathrm{mg}$ EB produced a more uniform emergence of the follicular wave and greater $\mathrm{P} / \mathrm{AI}$ after resynchronization, without compromising the pregnancy established at the first FTAI in suckled B. taurus and $B$ indicus beef cows. Preliminary results of a study (Prata and Sartori, 2016; ESALQ, USP, Piracicaba, SP, Brazil, unpublished) that is being performed with postpartum lactating Nelore cows followed a similar trend in P/AI for $1 v s .2 \mathrm{mg} \mathrm{EB}$ treatment at the initiation of a FTAI protocol $(40.9 \%$ [36/88] vs. 47.2\% [42/89]; $\mathrm{P}=0.40)$ but was not significantly different (day 0: $\mathrm{EB}+\mathrm{P} 4$ insert; day 8: P4 insert removal, $0.6 \mathrm{mg} \mathrm{ECP}, 500 \mu \mathrm{g}$ cloprostenol, and 300 IU eCG; day 10: FTAI). 


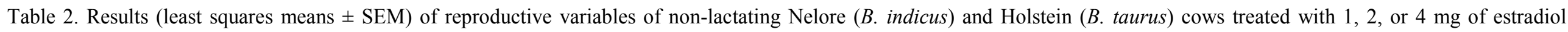
benzoate (EB) and an intravaginal progesterone insert.

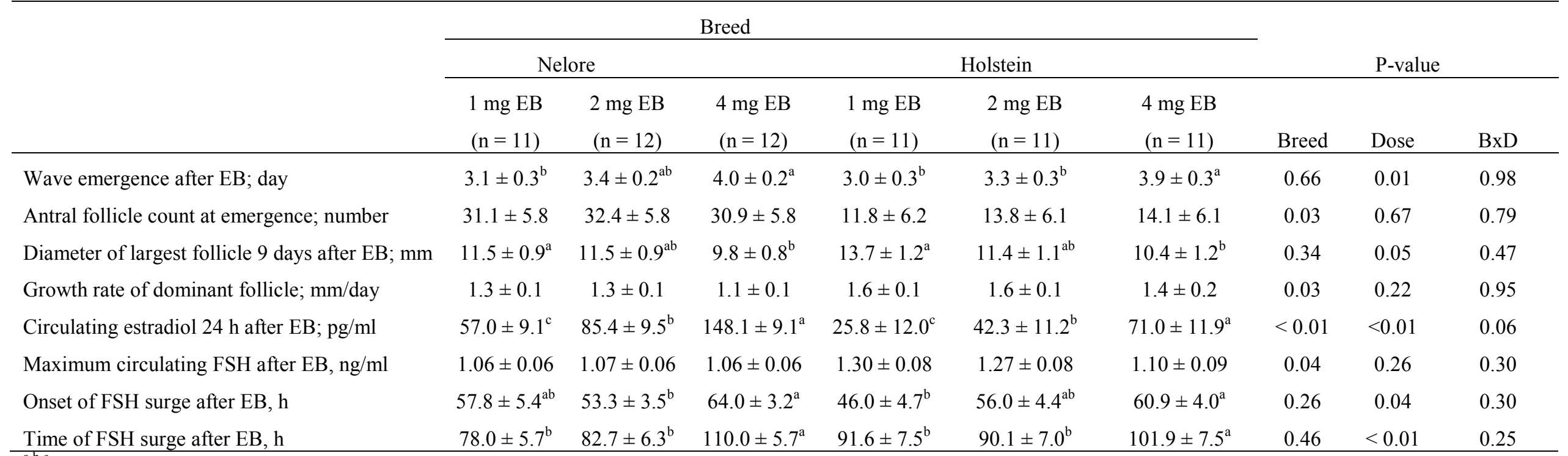

${ }^{a, b, c}$ Effect of dose within breed $(\mathrm{P}<0.05)$. 
Corpus luteum function, luteolysis, and growth and ovulation of the preovulatory follicle

Despite having smaller CL, B. indicus have greater circulating $\mathrm{P} 4$, probably due to greater production, but also, a reduced metabolic clearance rate for P4 than in B. taurus (Sartori et al., 2016). Moreover, among $B$. taurus breeds, lactating dairy cows have even lower circulating steroid hormones (Sartori et al., 2002a, 2004) due to greater metabolic clearance associated with greater dry matter intake (Sangsritavong et al., 2002; Vasconcelos et al., 2003).

One of the first studies (Carvalho et al., 2008) to suggest lower P4 clearance rates in $B$. indicus than $B$. taurus was done using 70 nulliparous heifers of different genetic groups [B. indicus (Nelore and Gir), $B$. indicus $\mathrm{x} B$. taurus (Nelore $\mathrm{x}$ Angus and Gir $\mathrm{x}$ Holstein), B. taurus (Angus and Holstein)]. Two PGF2 $\alpha$ treatments were performed 24 and 12 days (day -24 and day -12) before a P4 implant insertion. On day 0, each heifer received the $\mathrm{P} 4$ implant, and $2 \mathrm{mg} \mathrm{EB}$. In addition, half of the heifers from each genetic group received $25 \mathrm{mg}$ of PGF $2 \alpha$ on day 0 . A second PGF $2 \alpha$ treatment was performed on all heifers at the time of $\mathrm{P} 4$ implant withdrawal (day 8). On day 9, all heifers received $1 \mathrm{mg}$ EB. There were no detectable differences in serum $\mathrm{P} 4$ concentrations among genetic groups on day 0 , but $\mathrm{P} 4$ concentrations were greater on day $3(\mathrm{P}<0.05)$ in $B$. indicus $(6.8 \pm 0.8 \mathrm{ng} / \mathrm{ml})$ and $B$. indicus $\times$ B $B$. taurus $(5.7 \pm 0.7 \mathrm{ng} / \mathrm{ml})$ than in $B$. taurus $(3.9 \pm 0.4 \mathrm{ng} / \mathrm{ml})$ heifers. Circulating P4 in B. indicus heifers on day 6 (5.7 $\pm 0.6^{\mathrm{a}}$ vs. $4.0 \pm 0.6^{\mathrm{b}}$ vs. $\left.3.2 \pm 0.5^{\mathrm{b}} \mathrm{ng} / \mathrm{ml}\right)$ and day $8(5.3 \pm$ $0.7^{\mathrm{a}}$ vs. $3.3 \pm 0.4^{\mathrm{b}}$ vs. $\left.3.0 \pm 0.5^{\mathrm{b}} \mathrm{ng} / \mathrm{ml}\right)$ exceeded $\left({ }^{\mathrm{a}, \mathrm{b}} \mathrm{P}<\right.$ 0.05 ) those of $B$. indicus $\times$ B . taurus or $B$. taurus heifers, respectively. These results were corroborated by another study (Nascimento et al., 2012; Sartori et al., 2016) designed to compare circulating $\mathrm{P} 4$ profile in nonlactating Holstein $(n=20)$ and Nelore $(n=20)$ cows fed a maintenance diet after insertion of intravaginal P4 inserts. Cows did not have a functional $\mathrm{CL}$ at the time of implant insertion. There was an effect $(\mathrm{P}<0.05)$ of breed $(1.2 \mathrm{vs}$. $2.2 \mathrm{ng} / \mathrm{ml}$, Holstein and Nelore, respectively), in which P4 concentrations were about $90 \%$ greater in Nelore than in Holstein cows, probably due the greater P4 metabolism in Holsteins (Fig. 2A). After removal of the P4 device, blood was sampled every 40 minutes $(0.65 \mathrm{~h})$ until 240 min, and a lower P4 concentration was observed in Holstein than in Nelore cows (Fig. 2B).
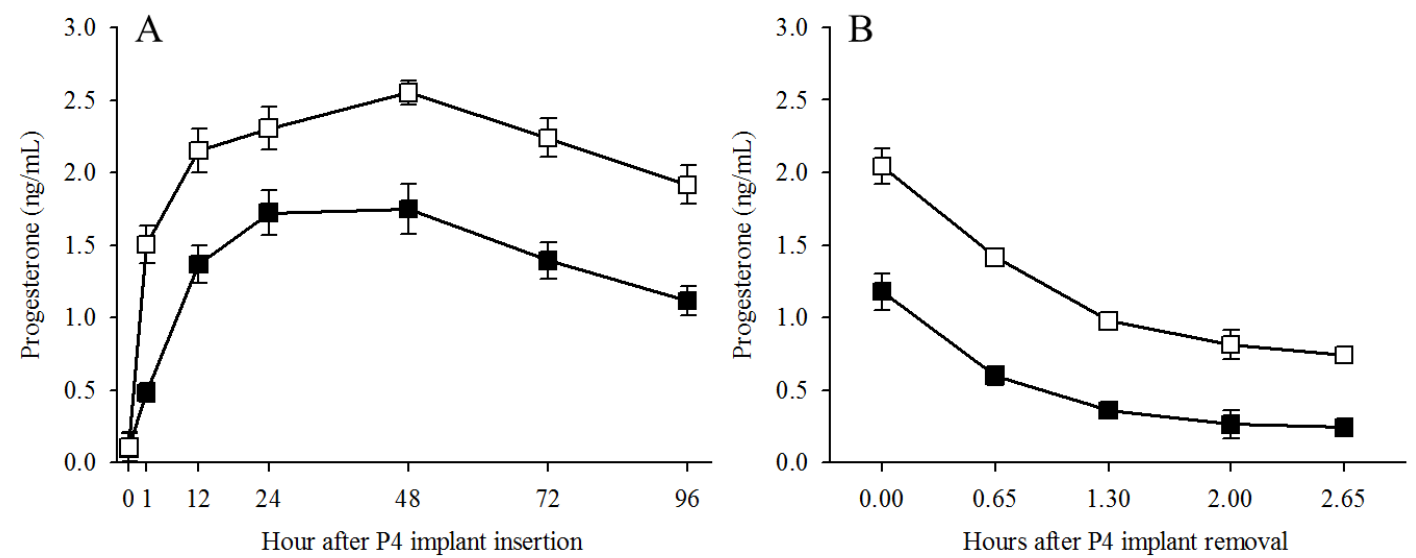

Figure 2. Circulating progesterone $(\mathrm{P} 4)$ concentrations (least squares means \pm standard error) of non-lactating Holstein $(\mathrm{n}=20 ; \boldsymbol{\square})$ and Nelore $(\mathrm{n}=20 ; \square)$ cows fed with a maintenance diet. (A) Blood was sampled before $(0 \mathrm{~h})$, and $1,6,12,24$, and $48 \mathrm{~h}$ after $\mathrm{P} 4$ implant insertion. There were effects of breed and day $(\mathrm{P} \leq 0.05)$. (B) Blood was sampled immediately before $(0 \mathrm{~h})$ and $0.65,1.30,2.00$, and $2.65 \mathrm{~h}$ after P4 implant removal. There were effects of breed and day ( $\leq 0.05$; From Sartori et al., 2016).

It has been shown that serum LH concentrations during the natural (Randel, 1976; Randel and Moseley, 1977), E2-induced (Rhodes et al., 1978), or GnRH-induced (Griffin and Randel, 1978) preovulatory LH-surge were lower in Brahman $(B$. indicus) than in British (B. taurus) breeds. Likewise, as discussed by Bó et al. (2003), gonadotrophin secretion patterns in the postpartum period also differ between $B$. taurus and $B$. indicus. Under the same conditions, $B$. taurus (Hereford $\times$ Shorthorn suckled cows) had higher plasma LH concentrations $(0.7 \pm 0.1 \mathrm{ng} / \mathrm{ml})$ than suckled Brahman cows $(0.6 \pm 0.1 \mathrm{ng} / \mathrm{ml})$ after 30 days postpartum and this difference appeared to increase over time (D'Occhio et al., 1990). In addition, a greater proportion of $B$. taurus cows had a higher pulsatile LH secretion than $B$. indicus cows (D'Occhio et al., 1990). In this study, LH concentrations were also affected by body condition and postpartum management (D'Occhio et al., 1990) suggesting that nutrition is one of the major concerns when evaluating postpartum activity in $B$. indicus and B. taurus. Moreover, independent of breed, or genetic group, suckling cows have lower LH-pulse frequency than lactating cows not carrying calf (discussed by Stevenson and Lamb, 2016). Despite that, non-pregnant, lactating Holstein cows had greater LHpulse frequency than non-pregnant non-lactating Holstein cows (Vasconcelos et al., 2003). It has been shown that LH pulses are essential for growth of the dominant follicle (Ginther et al., 1996). Circulating P4 concentrations are expected to influence LH-pulse frequency because P4 inhibited the dominant follicle development in a dose-dependent manner (Adams et al., 1992; Santos et al., 2016). Therefore, cattle with too high of circulating $\mathrm{P} 4$, nursing cows, or cows under 
nutritional restrictions may have reduced development of the dominant/preovulatory follicle potentially leading to reduced likelihood of ovulation and reduced size of the ovulatory follicle, which may compromise fertility under these conditions. These problems may be even more likely in B. indicus due to several factors, such as described above.

The importance of circulating concentrations of P4 during development of the preovulatory follicle on ovulation and fertility in cattle has been discussed by several authors (Wiltbank et al., 2006; Carvalho et al., 2008; Santos et al., 2016; Stevenson and Lamb, 2016). The general idea is that due to high LH-pulse frequency and physiologically low circulating P4 due to elevated steroid metabolism, lactating dairy cows ovulate larger follicles, and have high incidence of double ovulations, however oocyte and embryo quality may be hampered (Sartori et al., 2002b; Wiltbank et al., 2006, 2014; Santos et al., 2016). In B. taurus beef cattle, Stevenson and Lamb (2016) reported little effect of P4 environment during development of the preovulatory follicle on pregnancy risk. Moreover, Holstein heifers that received PGF2 $\alpha$ at the initiation of a Cosynch + CIDR protocol, and therefore, had lower circulating P4 during the protocol, resulting in larger ovulatory follicles, had similar $\mathrm{P} / \mathrm{AI}$ as heifers not receiving PGF $2 \alpha$ at the initiation of the protocol (Stevenson et al., 2008). In contrast, studies in $B$. indicus heifers or nonlactating cows indicated that high circulating P4 concentrations during synchronization of ovulation protocols reduced the growth of the dominant follicle, which negatively affected ovulation rate and pregnancy success (Carvalho et al., 2008; Dias et al., 2009; Peres et al., 2009).

The results presented above may explain the contrasting differences regarding the effects of equine chorionic gonadotrophin (eCG) at the end of a FTAI protocol on final follicle development and ovulation between $B$. indicus and $B$. taurus. Whereas in $B$. indicus, the majority of studies has shown a positive effect of eCG on percentage of heifers or cows that ovulate at the end of the protocol, greater circulating P4 during the subsequent diestrus, and improved P/AI (Baruselli et al., 2004; Peres et al., 2009; Sá Filho et al., 2009, 2010a, b; Lemes et al., 2011; Sales et al., 2011), data in B. taurus are conflicting and, although some studies in beef cattle have shown improved ovulation rate and fertility by adding eCG to the FTAI protocol (Pessoa et al., 2016), several studies have shown no or little benefit of eCG, especially in lactating Holstein cows (Small et al., 2009; Souza et al., 2009; Ferreira et al., 2013; Pulley et al., 2013).

Regarding induced luteolysis by exogenous treatments, the responsiveness of CL to PGF $2 \alpha$ seems to be very similar between $B$. indicus and $B$. taurus. To study the effect of the dose of a PGF $2 \alpha$ analog and day of the estrous cycle at the time of treatment, Ferraz Jr et al. (2016) performed an experiment with non-lactating Nelore cows, in a $3 \times 2$ factorial design, in which three different doses of dinoprost tromethamine $(12.5,25.0$, and $50.0 \mathrm{mg}$ ) were used on days 5 or 7 of the estrous cycle. In this study luteolysis was dose-dependent.
Therefore, increasing the dose of PGF $2 \alpha$ increased the proportion of cows detected in estrus and augmented the percentage of cows with circulating $\mathrm{P} 4$ concentration $<1.0 \mathrm{ng} / \mathrm{ml}$ at $72 \mathrm{~h}$ after PGF2 $\alpha$ treatment. Similar results were reported by Nascimento et al. (2014) who found that complete luteolysis did not occur in nonlactating Holstein cows on day 5 of the estrous cycle with either a full dose of PGF $2 \alpha$ (25 mg of dinoprost tromethamine), two full doses $8 \mathrm{~h}$ apart, or double dose (50.0 mg). Giordano et al. (2013) evaluated whether increasing the dose of PGF $2 \alpha$ (cloprostenol) during the Breeding-Ovsynch portion of the Double-Ovsynch protocol could improve the rates of ovulation and luteolysis and therefore increase P/AI. The authors observed a better luteolytic response to PGF $2 \alpha$ ( $\%$ of cows with complete CL regression) when the dose was increased from $500 \mu \mathrm{g}$ to $750 \mu \mathrm{g}$ in lactating Holstein cows $(84.3$ vs. $90.8 \% ; \quad \mathrm{P}=0.03)$. The greater cloprostenol dose increased luteal regression primarily in multiparous cows and increased fertility $(P=0.05)$ only at the pregnancy diagnosis 39 days after FTAI.

In addition to the dose of PGF $2 \alpha$, it is well known that the day of the estrous cycle impacts the proportion of cows with luteolysis after PGF2 $\alpha$ (dinoprost tromethamine) treatment. Ferraz $\mathrm{Jr}$ et al. (2016) observed that Nelore cows that had CL on day 5 of the estrous cycle were more refractory to PGF $2 \alpha$ than those on day 7 of the cycle. Moreover, in lactating Holstein cows, a second treatment of dinoprost tromethamine (+PGF2 $\alpha ; 24 \mathrm{~h}$ apart) increased the percentage of cows that had complete luteal regression (95.6\%) compared with control cows (84.6\%). Although one study found no detectable effect of the additional PGF $2 \alpha$ on P/AI (control $=41.5 \%$ vs. + PGF $2 \alpha=44.7 \%$; $\mathrm{P}=0.34$; Brusveen et al., 2009), recent studies have found significant improvements in P/AI when a second PGF2 $\alpha$ treatment is given, particularly in multiparous cows (Carvalho et al., 2015; Wiltbank et al., 2015). Therefore, complete luteolysis is essential to optimize ovulation and fertility to a FTAI protocol. In fact, more lactating Holstein cows with $\mathrm{P} 4<0.1 \mathrm{ng} / \mathrm{ml}$, compared with $\mathrm{P} 4 \geq 0.1$ and $<0.22 \mathrm{ng} / \mathrm{mL}$ at the time of $\mathrm{AI}$, ovulated to an E2/P4-based FTAI protocol (81.2 vs. $58.0 \%$ ) and had increased P/AI (47.4 vs. 21.4\%; Monteiro Jr et al., 2015a). Similar results were observed by Pereira et al. (2013b) when lactating dairy cows were also synchronized with an E2/P4-based protocol and were either inseminated or served as embryo recipients. The $\mathrm{P} 4$ concentration at the time of $\mathrm{AI}$ or 7 days before embryo transfer (ET) altered fertility in FTAI cows, with higher P/AI in cows with P4 concentration $<0.1 \mathrm{ng} / \mathrm{ml}$ compared with cows with $\mathrm{P} 4$ concentration $\geq 0.1 \mathrm{ng} / \mathrm{ml}$. In ET cows, higher $\mathrm{P} / \mathrm{ET}$ was found in cows with P4 concentration $<0.22 \mathrm{ng} / \mathrm{ml}$ compared with cows with $\mathrm{P} 4$ concentration $\geq 0.22 \mathrm{ng} / \mathrm{ml}$.

\section{Practical implications of the physiological differences between $B$. indicus and $B$. taurus for embryo production}

The physiological differences between $B$. indicus and B. taurus described above, need also to be 
considered when managing females for in vivo derived (IVD) embryos by multiple ovulation and embryo transfer (MOET) or in vitro embryo production (IVP).

One of the protocols most used in B. indicus cows and heifers for MOET was developed by Barros and Nogueira (2005) and was called P-36. The protocol included insertion of an intravaginal P4 insert for $36 \mathrm{~h}$ after PGF $2 \alpha$ administration and induction of ovulation with exogenous LH, administered $12 \mathrm{~h}$ after P4 insert removal ( $48 \mathrm{~h}$ after PGF2 $\alpha$ administration). The FTAI was performed 12 and $24 \mathrm{~h}$ later since ovulation occurs between 24 and $36 \mathrm{~h}$ after $\mathrm{LH}$ administration. The effectiveness of the P-36 protocol has been confirmed (Baruselli et al., 2006; Nogueira et al., 2007). A variation of the $\mathrm{P}-36$ protocol, in which the $\mathrm{P} 4$ device is removed $24 \mathrm{~h}$ after PGF2 $\alpha$ (protocol P-24) and $\mathrm{LH}$ is administered $24 \mathrm{~h}$ later ( $48 \mathrm{~h}$ after PGF2 $\alpha$ ), has been utilized in Nelore cattle, apparently with comparable results to those obtained with P-36 protocol (Baruselli et al., 2006).

The use of the P-36 protocol in B. taurus breeds, however, has resulted in decreased number of viable embryos in comparison with conventional protocols with estrus detection. In Holstein (Baruselli et al., 2006) and Angus donors (Bó et al., 2006), viable embryo production was increased with the P-36 protocol when the ovulation induction treatment ( $\mathrm{LH}$ or $\mathrm{GnRH})$ was administered at $60 \mathrm{~h}$ (P-36/LH60), rather than $48 \mathrm{~h}$ (P-36/LH48) after PGF2 $\alpha$ administration. On the other hand, even though delaying ovulation for $12 \mathrm{~h}$ in the P-36 protocol in B. taurus breeds (P-36/LH60 protocol) had positive effects on embryo production, the opposite occurred when used in B. indicus breeds. The P-36/LH60 protocol caused a decrease in embryo production when compared to $\mathrm{P}-36 / \mathrm{LH} 48$ protocol (Baruselli et al., 2006). Therefore, it can be inferred that ovulation in superstimulation protocols must be induced earlier in B. indicus donors; whereas, in B. taurus donors, it seems necessary to delay treatment with an ovulation inducer, thereby allowing an increase in follicle size, and acquisition of LH receptors.

Bos indicus breeds have a reduced capacity for LH secretion and a greater sensitivity to exogenous gonadotropins than B. taurus (Randel, 1984). Superovulatory response was evaluated in Nelore cows submitted to three different doses of Folltropin-V (100, 133 or $200 \mathrm{mg}$ ) in a crossover design. There were no significant differences in any of the variables evaluated, indicating that it was possible to reduce the dose of FSH to $100 \mathrm{mg}$ in Nelore cows submitted to a FTAI superstimulatory protocol, without compromising superovulatory response and embryo production (Baruselli et al., 2006). Other studies in Nelore heifers successfully induced superovulation and embryo production using a smaller dose of FSH (70 mg; Guardieiro et al., 2014), which is very unlikely to be effective in B. taurus.

Especially due to the greater AFC and better oocyte quality in $B$. indicus in relation to $B$. taurus, IVP is much more successful in $B$. indicus. For example, Gir (B. indicus), Holstein and crossbreds (1/4 Holstein x 3/4 Gir or $1 / 2$ Holstein-Gir) were compared for total and viable oocyte yield, and IVP embryos (Pontes et al., 2010). The number of total and viable oocytes, and embryos produced were greater in Gir than in Holstein cattle (17.1 vs. $11.4 ; 12.1$ vs. $8.0 ; 3.2$ vs. 2.2, respectively). Moreover, embryo production (5.5 blastocysts) was even greater in Holstein-Gir crossbreds compared to the other breeds. Another study was conducted to compare IVP between Nelore and Holstein heifers (Gimenes et al., 2015). More oocytes were recovered (37.1 vs. 15.4), more embryos were produced (7.3 vs. 1.1), and a greater blastocyst rate was obtained (28.3 vs. 14.1\%) from Nelore than Holstein heifers. In another study (Sales et al., 2015), Gir cows had a greater number of oocytes recovered by ovum pickup (OPU; 23.4 vs. 14.9), better quality of oocytes demonstrated by greater cleavage rates (73.6 vs. 40.8\%), greater number of blastocysts $(3.8 \mathrm{vs}$. 0.7$)$ and better blastocyst rates (36.7 vs. 12.1\%) than Holstein donors.

Overall, the main findings of the studies described above indicate that $B$. taurus yielded less oocytes, as well as produced less blastocysts per OPU than $B$. indicus donors. This pattern seems to occur even when other B. taurus breeds are studied. Sudano et al. (2014) conducted an experiment in which non-lactating Simmental (B. taurus) and Nelore cows were compared for in vivo embryo production and IVP. Although the total number of recovered ova/embryos per cow (5.5 vs. 3.7) and transferable IVD embryos per cow (3.8 vs. 2.3) were not different between Nelore and Simmental, respectively, when IVP was performed, Nelore produced more oocytes per OPU (14.9vs. 8.1) and had greater blastocyst rates per OPU (41.5 vs. 23.4\%) than Simmental cows. The potential impact of metabolic or steroid hormones, associated or not with different feed intake regimens on embryo production in $B$. indicus and $B$. taurus cattle, has been discussed in more details by Sartori et al. (2016).

\section{Final considerations}

Bos indicus and B. taurus have been mainly used for milk and beef production around the world. Although, in general, B. taurus have been more intensely selected for production, a better adaptation to the tropical and sub-tropical environments makes $B$. indicus and crossbreds feasible options for production. Moreover, there are significant differences in the reproductive physiology between those genetic groups that affect the application of adequate tools for reproductive management. For example, B. taurus in general reach puberty sooner (Sartori et al., 2010a) and have a shorter gestation length as compared to $B$. indicus (Paschal et al, 1991). Therefore, in order to have a 12-months calving interval, $B$. indicus cows must conceive 10 days earlier than $B$. taurus. Differences in estrus behavior and ovarian function also make some adjustments of reproductive management necessary. The greater sensitivity to the negative feedback of steroid hormones on the hypothalamus-pituitary axis makes a dose reduction sometimes necessary during hormone treatments in B. indicus. On the other hand, due to greater steroid hormone clearance, especially in 
lactating $B$. taurus dairy cows, higher doses of hormones may be necessary to optimize reproductive management strategies. Moreover, the greater AFC, greater oocyte quality, and greater sensitivity to gonadotropins in $B$. indicus, make embryo production much more affordable than in $B$. taurus.

\section{Acknowledgments}

We thank all the students, institutions and companies that have collaborated with our research, as well as the funding agencies FAPESP, CNPq, and CAPES of Brazil.

\section{References}

Adams GP, Matteri RL, Ginther OJ. 1992. Effect of progesterone on ovarian follicles, emergence of follicular waves and circulating follicles-stimulatinghormone in heifers. J. Reprod Fertil, 96:627-640.

Alvarez P, Spicer LJ, Chase CC, Payton ME, Hamilton TD, Stewart RE, Hammond AC, Olson TA, Wettemann RP. 2000. Ovarian and endocrine characteristics during an estrous cycle in Angus, Brahman, and Senepol cows in a subtropical environment. J Anim Sci, 78:1291-1302.

Ayres H, Martins CM, Ferreira RM, Mello JE, Dominguez JH, Souza AH, Valentin R, Santos ICC, Baruselli PS. 2008. Effect of timing of estradiol benzoate administration upon synchronization of ovulation in suckling Nelore cows (Bos indicus) treated with a progesterone-releasing intravaginal device. Anim Reprod Sci, 109:77-87.

Baldrighi JM, Sa Filho MF, Batista EOS, Lopes RNVR, Visintin JA, Baruselli PS, Assumpção MEO. 2014. Anti-mullerian hormone concentration and antral ovarian follicle population in Murrah heifers compared to Holstein and Gyr kept under the same management. Reprod Domest Anim, 49:1015-1020.

Barros CM, Nogueira MFG. 2005. Superovulation in zebu cattle: protocol P-36. Embryo Transfer Newsletter, 23:5-9.

Baruselli PS, Reis EL, Marques MO, Nasser LF, Bó GA. 2004. The use of hormonal treatments to improve reproductive performance of anestrous beef cattle in tropical climates. Anim Reprod Sci, 82/83:479-486.

Baruselli PS, de Sá Filho MF, Martins CM, Nasser LF, Nogueira MFG, Barros CM, Bo GA. 2006. Superovulation and embryo transfer in Bos indicus cattle. Theriogenology, 65:77-88

Bastos MR, Mattos MCC, Meschiatti MAP, Surjus RS, Guardieiro MM, Ferreira JCP, Mourão GB, Pires AV, Biehl MV, Pedroso AM, Santos FAP, Sartori R. 2010. Ovarian function and circulating hormones in nonlactating Nelore versus Holstein cows. Acta Sci Vet, 38(suppl. 2):776. (abstract).

Bastos MR, Surjus RS, Prata AB, Meschiatti MAP, Borsato M, Mourão GB, Pedroso AM, Pires AV, Sartori R. 2011. Dose effect of estradiol benzoate associated with progesterone on the synchronization of follicular wave emergence in Bos indicus and Bos taurus cows. Acta Sci Vet, 39(suppl. 1):315. (abstract).
Batista EOS, Macedo GG, Sala RV, Ortolan MDDV, Sa Filho MF, Del Valle TA, Jesus EF, Lopes RNVR, Renno FP, Baruselli PS. 2014. Plasma antimullerian hormone as a predictor of ovarian antral follicular population in Bos indicus (Nelore) and Bos taurus (Holstein) heifers. Reprod Domest Anim, 49:448-452.

Biehl MV, Pires AV, Ferraz Junior MVC, Nepomuceno DD, Ferreira EM, Gentil1 RS, Cruppe LH, Day ML. 2013. Reproductive performance of Bos indicus heifers with reduced serum progesterone concentration at the onset of a 5-d Co-Synch + CIDR program. J Anim Sci, 91(E-suppl. 2):353. (abstract).

Bo GA, Adams GP, Nasser LF, Pierson RA, Mapletoft R J. 1993. Effect of estradiol valerate on ovarian follicles, emergence of follicular waves and circulating gonadotropins in heifers. Theriogenology, 40:225-239.

Bo GA, Adams GP, Pierson RA, Tribulo HE, Caccia M, Mapletoft R. 1994. Follicular wave dynamics after estradiol-17-beta treatment of heifers with or without a progestogen implant. Theriogenology, 41:1555-1569.

Bo GA, Adams GP, Caccia M, Martinez M, Pierson RA, Mapletoft RJ. 1995. Ovarian follicular wave emergence after treatment with progestogen and estradiol in cattle. Anim Reprod Sci, 39:193-204.

Bó GA , Baruselli PS, Martínez, MF. 2003. Pattern and manipulation of follicular development in Bos indicus cattle. Anim Reprod Sci, 78:307-326.

Bó GA, Baruselli PS, Chesta PM, Martins CM. 2006. The timing of ovulation and insemination schedules in superstimulated cattle. Theriogenology, 65:89-101

Bridges GA, Helser LA, Grum DE, Mussard ML, Gasser CL, Day ML. 2008. Decreasing the interval between GnRH to PGF2 $\alpha$ from 7 to 5 days and lengthening proestrus increases timed-AI pregnancy rates in beef cows. Theriogenology, 69:843-851.

Brusveen DJ, Souza AH, Wiltbank MC. 2009. Effects of additional prostaglandin F-2 alpha and estradiol-17 beta during Ovsynch in lactating dairy cows. $J$ Dairy Sci, 92:1412-1422.

Carvalho JBP, Carvalho NAT, Reis EL, Nichi M, Souza AH, Baruselli PS. 2008. Effect of early luteolysis in progesterone-based AI protocols in Bos indicus, Bos indicus $\mathrm{x}$ Bos taurus and Bos taurus heifers. Theriogenology, 69:167-175.

Carvalho PD, Fuenzalida MJ, Ricci A, Souza AH, Barletta RV, Wiltbank MC, Fricke PM. 2015. Modifications to Ovsynch improve fertility during resynchronization: evaluation of presynchronization with gonadotropin-releasing hormone 6 day before initiation of Ovsynch and addition of a second prostaglandin F2 $\alpha$ treatment. J Dairy Sci, 98:8741-8752. Cerri RLA, Rutigliano HM, Chebel RC, Santos JEP. 2009. Period of dominance of the ovulatory follicle influences embryo quality in lactating dairy cows. Reproduction, 137:813-823.

Chenault JR, Kratzer DD, Rzepkowski RA, Goodwin MC. 1990. LH and FSH response of Holstein heifers to fertirelin acetate, gonadorelin and buserelin. Theriogenology, 34:81-98.

Colazo MG, Kastelic JP, Davis H, Rutledge MD, Martinez MF, Small JA, Mapletoft RJ. 2008. Effects 
of plasma progesterone concentrations on $\mathrm{LH}$ release and ovulation in beef cattle given GnRH. Domest Anim Endocrinol, 34:109-117.

Dias CC, Wechsler FS, Day ML, Vasconcelos JLM. 2009. Progesterone concentrations, exogenous equine chorionic gonadotropin, and timing of prostaglandin F $2 \alpha$ treatment affect fertility in postpuberal Nelore heifers. Theriogenology, 72:378-385.

Dias HP, Albuquerque JP, Castilho ACS, Vasconcelos JLM. 2014. High progesterone concentration has a negative effect on the expression of LH receptors in granulosa cells from Nelore heifers. Anim Reprod, 11:366. (abstract).

D'Occhio MJ, Neish A, Broadhurst L. 1990. Differences in gonadotrophin secretion postpartum between Zebu and European breed cattle. Anim Reprod Sci, 22:311-317.

Fernandes P, Teixeria AB, Crocci AJ, Barros CM 2001. Timed artificial insemination in beef cattle using GnRH agonist, PGF2alpha and estradiol benzoate. Theriogenology, 55:1521-1532.

Ferraz Junior MVC, Pires AV, Biehl MV, Santos MH, Barroso JPR, Gonçalves JR, Sartori R, Day ML. 2016. Comparison of two different timed AI system schemes to synchronize estrus and ovulation in Nellore cattle.

doi:10.1016/j.theriogenology.2016.06.012.

Ferreira RM, Ayres H, Sales JN, Souza AH, Rodrigues CA, Baruselli PS. 2013. Effect of different doses of equine chorionic gonadotropin on follicular and luteal dynamics and P/AI of high-producing Holstein cows. Anim Reprod Sci, 140:26-33.

Figueiredo RA, Barros CM, Pinheiro OL, Soler JM. 1997. Ovarian follicular dynamics in Nelore breed (Bos indicus) cattle. Theriogenology, 47:1489-1505.

Fricke PM, Carvalho PD, Giordano JO, Valenza A, Lopes G Jr, Amundson MC. 2014. Expression and detection of estrus in dairy cows: the role of new technologies. Animal, 8:134-143.

Gandra JR, Freitas JE, Barletta RV, Maturana M, Gimenes LU, Vilela FG, Baruselli PS, Renno FP. 2011. Productive performance, nutrient digestion and metabolism of Holstein (Bos taurus) and Nellore (Bos taurus indicus) cattle and Mediterranean buffaloes (Bubalis bubalis) fed with corn-silage based diets. Livest Sci, 140:283-291.

Gimenes LU, Sa MF, Carvalho NAT, Torres JRS, Souza AH, Madureira EH, Trinca LA, Sartorelli ES, Barros CM, Carvalho JBP, Mapletoft RJ, Baruselli PS. 2008. Follicle deviation and ovulatory capacity in Bos indicus heifers. Theriogenology, 69:852-858.

Gimenes LU, Ferraz ML, Fantinato-Neto P, Chiaratti MR, Mesquita LG, Sa Filho MF, Meirelles FV, Trinca LA, Renno FP, Watanabe YF, Baruselli PS. 2015. The interval between the emergence of pharmacologically synchronized ovarian follicular waves and ovum pickup does not significantly affect in vitro embryo production in Bos indicus, Bos taurus, and Bubalus bubalis. Theriogenology, 83:385-393.

Ginther OJ, Kastelic JP, Knopf L. 1989. Intraovarian relationships among dominant and subordinate follicles and the corpus luteum in heifers. Theriogenology,

\section{2:787-795}

Ginther OJ, Wiltbank MC, Fricke PM, Gibbons JR, Kot K. 1996. Selection of the dominant follicle in cattle. Biol Reprod, 55:1187-1194.

Giordano JO, Fricke PM, Guenther JN, Lopes Jr G, Herlihy MM, Nascimento AB, Wiltbank MC. 2012a. Effect of progesterone on magnitude of the luteinizing hormone surge induced by two different doses of gonadotropin-releasing hormone in lactating dairy cows. J Dairy Sci, 95:3781-3793.

Giordano JO, Wiltbank MC, Guenther JN, Pawlisch R, Bas S, Cunha AP, Fricke PM. 2012b. Increased fertility in lactating dairy cows resynchronized with Double-Ovsynch compared with Ovsynch initiated $32 \mathrm{~d}$ after timed artificial insemination. J Dairy Sci, 95:639653.

Giordano JO, Wiltbank MC, Fricke PM, Bas S, Pawlisch R, Guenther JN, Nascimento AB. 2013. Effect of increasing GnRH and PGF(2 alpha) dose during Double-Ovsynch on ovulatory response, luteal regression, and fertility of lactating dairy cows. Theriogenology, 80:773-783.

Griffin JL, Randel RD. 1978. Reproductive studies of Brahman cattle. II. Luteinizing hormone patterns in ovariectomized Brahman and Hereford cows before and after injection of gonadotropin releasing hormone. Theriogenology, 9:437-446.

Guardieiro MM, Machado GM, Bastos MR, Mourão GB, Carrijo LH, Dode MA, Leroy JL, Sartori R. 2014. A diet enriched in linoleic acid compromises the cryotolerance of embryos from superovulated beef heifers. Reprod Fertil Dev, 26:511-520.

Gumen A, Guenther JN, Wiltbank MC. 2003. Follicular size and response to Ovsynch versus detection of estrus in anovular and ovular lactating dairy cows. J Dairy Sci, 86:3184-3194.

Herlihy MM, Giordano JO, Souza AH, Ayres H, Ferreira RM, Keskin A, Nascimento AB, Guenther JN, Gaska JM, Kacuba SJ, Crowe MA, Butler ST, Wiltbank MC. 2012. Presynchronization with DoubleOvsynch improves fertility at first postpartum artificial insemination in lactating dairy cows. $J$ Dairy $S c i$, 95:7003-7014.

Lemes AP, Rodrigues ADP, Peres RFG, Graff, HB, Carvalho ER, Souza AH, Sartori R. 2011. Concepção em vacas Nelore pós-parto tratadas com eCG antes e/ou após inseminação artificial em tempo fixo. 2010. Acta Sci Vet, 39(suppl. 1):381. (abstract).

Lopez H, Satter LD, Wiltbank MC. 2004. Relationship between level of milk production and estrous behavior of lactating dairy cows. Anim Reprod Sci, 81:209-223.

Martinez MF, Adams GP, Bergfelt DR, Kastelic JP, Mapletoft RJ. 1999. Effect of LH or GnRH on the dominant follicle of the first follicular wave in beef heifers. Anim Reprod Sci, 57:23-33.

Martinez MF, Adams GP, Kastelic JP, Bergfelt DR, Mapletoft RJ. 2000. Induction of follicular wave emergence for estrus synchronization and artificial insemination in heifers. Theriogenology, 54:757-769.

Melo LF, Monteiro Jr PLJ, Surjus RS, Drum JN, Wiltbank MC, Sartori R. 2016. Progesterone-based 
fixed-time artificial insemination protocols for dairy cows: gonadotropin-releasing hormone versus estradiol benzoate at initiation and estradiol cypionate versus estradiol benzoate at the end. $J$ Dairy Sci. doi.org/10.3168/jds.2016-11220.

Meneghetti M, Sá Filho OG, Peres RF, Lamb GC, Vasconcelos JL. 2009. Fixed-time artificial insemination with estradiol and progesterone for Bos indicus cows I: basis for development of protocols. Theriogenology, 72:179-189.

Monteiro Jr PLJ, Borsato M, Silva FLM, Prata AB, Wiltbank MC, Sartori R. 2015a. Increasing estradiol benzoate, pretreatment with gonadotropin-releasing hormone, and impediments for successful estradiolbased fixed-time artificial insemination protocols in dairy cattle. J Dairy Sci, 98:3826-3839.

Monteiro Jr PLJ, Nascimento AB, Pontes GCS, Fernandes GO, Melo LF, Wiltbank MC, Sartori R. 2015b. Progesterone supplementation after ovulation: effects on corpus luteum function and on fertility of dairy cows subjected to AI or ET. Theriogenology, 84:1215-1224.

Nascimento AB, Monteiro Jr PLJ, Silva FLM, Guardieiro MM, Prata AB, Nogueira GP, Mourão GB, Wiltbank MC, Pires AV, Sartori R. 2012. Serum progesterone concentrations in Holstein and Nelore cows after the insertion of two different progesterone devices. J Dairy Sci, 95(suppl. 2):326. (abstract).

Nascimento AB, Souza AH, Keskin A, Sartori R, Wiltbank MC. 2014. Lack of complete regression of the day 5 corpus luteum after one or two doses of PGF $2 \alpha$ in nonlactating Holstein cows. Theriogenology, 81:389-395.

Nogueira MFG, Fragnito PS, Trinca LA, Barros CM. 2007. The effect of type of vaginal insert and dose of pLH on embryo production, following fixed-time AI in a progestin-based superstimulatory protocol in Nelore cattle. Theriogenology, 67:655-660.

Paschal JC, Sanders JO, Kerr JL. 1991. Calving and weaning characteristics of Angus-, Gray Brahman-, Gir, Indu-Brazil-, Nellore-, and Red Brahman-sired F1 calves. J Anim Sci, 69:2395-2402.

Pereira MHC, Rodrigues ADP, Martins T, Oliveira WVC, Silveira PSA, Wiltbank MC, Vasconcelos JLM. 2013a. Timed artificial insemination programs during the summer in lactating dairy cows: Comparison of the 5-d Cosynch protocol with an estrogen/progesterone-based protocol. $J$ Dairy Sci, 96:6904-6914.

Pereira MHC, Sanches CP, Guida TG, Rodrigues ADP, Aragon FL, Veras MB, Borges PT, Wiltbank MC, Vasconcelos JLM. 2013b. Timing of prostaglandin F-2 alpha treatment in an estrogen-based protocol for timed artificial insemination or timed embryo transfer in lactating dairy cows. J Dairy Sci, 96:2837-2846.

Peres RFG, Claro Júnior I, Sá Filho OG, Nogueira GP, Vasconcelos JLM. 2009. Strategies to improve fertility in Bos indicus postpubertal heifers and nonlactating cows submitted tofixed-time artificial insemination. Theriogenology, 72:681-689.

Perry GA, Perry BL. 2009. Effect of the timing of controlled internal drug-releasing device insertion on the gonadotropin-releasing hormone-induced luteinizing hormone surge and ovulatory response. J Anim Sci, 87:3983-3990.

Pessoa GA, Martini AP, Chaiben MFC, Vieira LM, Girotto RW, Pugliesi G, Santin T, Rubin MIB, Baruselli PS, Sá Filho MF. 2015. Adjustment of the estradiol benzoate dose in the resynchronization protocol with unknown pregnancy status in suckled beef cows. Anim Reprod, 12:610. (abstract).

Pessoa GA, Martini AP, Carloto GW, Rodrigues MCC, Claro Junior I, Baruselli PS, Brauner CC, Rubin MIB., Correa MN, Leivas FG, Sá Filho MF. 2016. Different doses of equine chorionic gonadotropin on ovarian follicular growth and pregnancy rate of suckled Bos taurus beef cows subjected to timed artificial insemination protocol. Theriogenology, 85:792-799.

Picard-Hagen N, Lhermie G, Florentin S, Merle D, Frein P, Gayrard V. 2015. Effect of gonadorelin, lecirelin, and buserelin on LH surge, ovulation, and progesterone in cattle. Theriogenology, 84:177-183.

Pinheiro OL, Barros CM, Figueiredo RA, Valle ER, Encarnação RO, Padovani CR. 1998. Estrus behavior and the estrus to ovulation interval in Nelore cattle (Bos indicus) with natural estrus or estrus induced with prostaglandin F2alpha or norgestomet and estradiol valerate. Theriogenology, 49:667-681.

Pontes JH, Silva KC, Basso AC, Rigo AG, Ferreira CR, Santos GM, Sanches BV, Porcionato JP, Vieira PH, Faifer FS, Sterza FA, Schenk JL, Seneda MM. 2010. Large-scale in vitro embryo production and pregnancy rates from Bos taurus, Bos indicus, and indicus-taurus dairy cows using sexed sperm. Theriogenology, 74:1349-1355.

Pulley SL, Wallace LD, Mellieon Jr HI, Stevenson JS. 2013. Ovarian characteristics, serum concentrations of progesterone and estradiol, and fertility in lactating dairy cows in response to equine chorionic gonadotropin. Theriogenology, 79:127-134.

Pursley JR, Mee MO, Wiltbank MC. 1995. Synchronization of ovulation in dairy-cows using PGF(2-alpha), and GnRH. Theriogenology, 44:915-923.

Pursley JR, Wiltbank MC, Stevenson JS, Ottobre JS, Garverick HA, Anderson LL. 1997. Pregnancy rates per artificial insemination for cows and heifers inseminated at a synchronized ovulation or synchronized estrus. J Dairy Sci, 80:295-300.

Randel RD. 1976. LH and ovulation in Brahman, Brahman x Hereford and Hereford heifers. J Anim Sci, 43:300. (abstract).

Randel RB. 1984. Seasonal effects on female reproductive on female reproductive functions in the bovine (indian breeds). Theriogenology, 21:170-185.

Randel RD, Moseley WM. 1977. Serum luteinizing hormone surge and progesterone near estrus in Brahman, Brahman $\times$ Hereford and Hereford heifers. $J$ Anim Sci, 45:199. (abstract).

Rhodes FM, De'ath G, Entwistle KW. 1995. Animal and temporal effects on ovarian follicular dynamics in Brahman heifers. Anim Reprod Sci, 38:265-277.

Rhodes III RC, Randel RD, Harms PG. 1978. Reproductive studies of Brahman cattle. IV. Luteinizing 
hormone levels in ovariectomized in Brahman, Brahman $\times$ Hereford and Hereford cows following a 20 $\mathrm{mg}$ dose of estradiol-17. Theriogenology, 10:429-437.

Ribeiro ES, Galvão KN, Thatcher WW, Santos JEP. 2012. Economics aspects of applying reproductive technologies to dairy herds. Anim Reprod, 9:370-387.

Sá Filho OG, Meneghetti M, Peres RFG, Lamb GC, Vasconcelos JLM. 2009. Fixed-time artificial insemination with estradiol and progesterone for Bos indicus cows II: Strategies and factors affecting fertility. Theriogenology, 72:210-218.

Sá Filho MF, Ayres H, Ferreira RM, Marques MO, Reis EL, Silva RCP, Rodrigues CA, Madureira EH, Bó GA, Baruselli PS. 2010a. Equine chronic gonadotropin and gonadotropin-releasing hormone enhance fertility in a norgestomet-based, timed artificial insemination protocol in sucked Nellore (Bos indicus) cows. Theriogenology, 73:651-658.

Sá Filho MF, Torres-Júnior JRS, Penteado L, Gimenes LU, Ferreira RM, Ayres H, Castro e Paula LA, Sales JNS, Baruselli PS. 2010b. Equine chronic gonadotropin improves the efficacy of a progestinbased fixed-time artificial insemination protocol in Nellore (Bos indicus) heifers. Anim Reprod Sci, 118:182-187.

Sá Filho MF, Baldrighi JM, Sales JN, Crepaldi GA, Carvalho JB, Bó GA, Baruselli PS. 2011. Induction of ovarian follicular wave emergence and ovulation in progestin-based timed artificial insemination protocols for Bos indicus cattle. Anim Reprod Sci, 129:132-139.

Sales JNS, Crepaldi GA, Girotto RW, Souza AH, Baruselli PS. 2011. Fixed time AI protocols replacing eCG with a single dose of FSH were less effective in stimulating follicular growth, ovulation, and fertility in suckled-anestrus Nelore beef cows. Anim Reprod Sci, 124:12-18

Sales JNS, Iguma LT, Batista RITP, Quintao CCR, Gama MAS, Freitas C, Pereira MM, Camargo LSA, Viana JHM, Souza JC, Baruselli PS. 2015. Effects of a high-energy diet on oocyte quality and in vitro embryo production in Bos indicus and Bos taurus cows. J Dairy Sci, 98:3086-3099.

Sangsritavong S, Combs DK, Sartori R, Armentano LE, Wiltbank MC. 2002. High feed intake increases liver blood flow and metabolism of progesterone and estradiol-17 beta in dairy cattle. $J$ Dairy Sci, 85:28312842 .

Santos JEP, Rutigliano HM, Sa Filho MF. 2009. Risk factors for resumption of postpartum estrous cycles and embryonic survival in lactating dairy cows. Anim Reprod Sci, 110:207-221.

Santos JEP, Bisinotto RS, Ribeiro ES. 2016. Mechanisms underlying reduced fertility in anovular dairy cows. Theriogenology, 86:254-262.

Sartorelli ES, Carvalho LM, Bergfelt DR, Ginther OJ, Barros CM. 2005. Morphological characterization of follicle deviation in Nelore (Bos indicus) heifers and cows. Theriogenology, 63:2382-2394.

Sartori R, Fricke PM, Ferreira JCP, Ginther OJ, Wiltbank MC. 2001. Follicular deviation and acquisition of ovulatory capacity in bovine follicles. Biol Reprod, 65:1403-1409.
Sartori R, Rosa GJM, Wiltbank MC. 2002a. Ovarian structures and circulating steroids in heifers and lactating cows in summer and lactating and dry cows in winter. J Dairy Sci, 85:2813-2822.

Sartori R, Sartor-Bergfelt R, Mertens SA, Guenther JN, Parrish JJ, Wiltbank MC. 2002b. Fertilization and early embryonic development in heifers and lactating cows in summer and lactating and dry cows in winter. J Dairy Sci, 85:2803-2812.

Sartori R, Haughian JM, Shaver RD, Rosa GJM, Wiltbank MC. 2004. Comparison of ovarian function and circulating steroids in estrous cycles of Holstein heifers and lactating cows. J Dairy Sci, 87:905-920.

Sartori R, Bastos MR, Baruselli PS, Gimenes LU, Ereno RL, Barros CM. 2010a. Physiological differences and implications to reproductive management of Bos taurus and Bos indicus cattle in a tropical environment. Soc Reprod Fertil Suppl, 67:357375.

Sartori R, Bastos MR, Mattos MCC. 2010b. Physiological bases for understanding estrous cycle differences between Bos taurus and Bos indicus. Acta Sci Vet, 38(supl 2):s287-s295.

Sartori R, Barros CM. 2011. Reproductive cycles in Bos indicus cattle. Anim Reprod Sci, 124:244-250.

Sartori R, Guardieiro MM, Surjus RS, Melo LF, Prata AB, Ishiguro M, Bastos MR, Nascimento AB. 2013. Metabolic hormones and reproductive function in cattle. Anim Reprod, 10:199-205.

Sartori R, Gimenes LU, Monteiro Jr PL, Melo LF, Baruselli PS, Bastos MR. 2016. Metabolic and endocrine differences between Bos taurus and Bos indicus females that impact the interaction of nutrition with reproduction. Theriogenology, 86:32-40.

Segerson EC, Hansen TR, Libby DW, Randel RD, Getz WR. 1984. Ovarian and uterine morphology and function in Angus and Brahman cows. Anim Sci, 59:1026-1046

Small JA, Colazo MG, Kastelic JP, Mapletoft R.J. 2009. Effects of progesterone presynchronization and eCG on pregnancy rates to GnRH-based, timed-AI in beef cattle. Theriogenology, 71:698-706.

Souza AH, Viechnieski S, Lima FA, Silva FF, Araújo R, Bó GA, Wiltbank MC, Baruselli PS. 2009. Effects of equine chorionic gonadotropin and type of ovulatory stimulus in a timed-AI protocol on reproductive responses in dairy cows. Theriogenology, 72:10-21.

Stevenson JL, Dalton JC, Santos JE, Sartori R, Ahmadzadeh A, Chebel RC. 2008. Effect of synchronization protocols on follicular development and estradiol and progesterone concentrations of dairy heifers. J Dairy Sci, 91:3045-3056.

StevensonJS, Lamb GC. 2016. Contrasting effects of progesterone on fertility of dairy and beef cows. $J$. Dairy Sci, 99:5951-5964.

Sudano MJ, Caixeta ES, Paschoal DM, Martins Jr A, Machado R, Buratini J, Landim-Alvarenga FDC. 2014. Cryotolerance and global gene-expression patterns of Bos taurus indicus and Bos taurus taurus in vitro- and in vivo produced blastocysts. Reprod Fertil Dev, 26:1129-1141.

Vasconcelos JLM, Silcox RW, Rosa GJM, Pursley 
JR, Wiltbank MC. 1999. Synchronization rate, size of the ovulatory follicle, and pregnancy rate after synchronization of ovulation beginning on different days of the estrous cycle in lactating dairy cows. Theriogenology, 52:1067-1078.

Vasconcelos JLM, Sartori R, Oliveira HN, Guenther JG, Wiltbank MC. 2001. Reduction in size of the ovulatory follicle reduces subsequent luteal size and pregnancy rate. Theriogenology, 56:307-314.

Vasconcelos JLM, Sangsritavong S, Tsai SJ, Wiltbank MC. 2003. Acute reduction in serum progesterone concentrations after feed intake in dairy cows. Theriogenology, 60:795-807.

Wiltbank MC, Gumen A, Sartori R. 2002. Physiological classification of anovulatory conditions in cattle. Theriogenology, 57:21-52.

Wiltbank M, Lopez H, Sartori R, Sangsritavong S, Gümen A. 2006. Changes in reproductive physiology of lactating dairy cows due to elevated steroid metabolism. Theriogenology, 65:17-29.

Wiltbank MC, Souza AH, Carvalho PD, Cunha AP, Giordano JO, Fricke PM, Baez GM, Diskin MG. 2014. Physiological and practical effects of progesterone on reproduction in dairy cattle. Animal, 8:70-81.

Wiltbank MC, Baez GM, Cochrane F, Barletta RV, Trayford CR, Joseph RT. 2015. Effect of a second treatment with prostaglandin F2 $\alpha$ during the Ovsynch protocol on luteolysis and pregnancy in dairy cows. $J$ Dairy Sci, 98:8644-8654. 